\title{
Kompetensi Amil, Persyaratan Sampai Pelaporan: Analisis Efektifitas UU Nomor 23 Tahun 2011 Di Lembaga Zakat Jawa Ttimur
}

\author{
Basar Dikuraisyin \\ UIN Sunan Ampel Surabaya \\ basardikuraisyin@uinsby.ac.id
}

\begin{abstract}
Abstrak
Penelitian ini berupaya untuk mengungkap efektifitas implementasi peraturan lembaga zakat di Jawa Timur. Karena belakangan terakhir Undang-Undang Nomor 23 Tahun 2011 banyak menuai protes dari lembaga zakat swasta yang terkesan "dinomor duakan" dan berada di bawah lembaga zakat baru yaitu Badan Amil Zakat bentukan pemerintah. Menurut sebagian LAZ, peraturan tersebut telah mereduksi dan membatasi gerak amil zakat swasta. Kemudian pada perjalannya, MK mengeluarkan putusan urgen dengan mengubah beberapa ketentuan. Signifikansi penelitian ini terletak pada indikator efektifitas dalam menjalankan aturan yang ada dianalisis terhadap kinerja yang sedang berjalan. Hal ini penting, mengingat keberadaan perundang-undangan adalah untuk ditaati dan dijalankan. Penelitian ini merupakan penelitian lapangan (field research) yang didekati dengan pendekatan kualitatif diskriptif. Pengumpulan data diambil dari wawancara dan observasi, yang kemudian diabsahkan menggunakan metode triangulasi sumber dan teknik. Setelah dilakukan penelitian dengan metodologis akurat, ditemukan beberapa hasil penelitian. 1) dari aspek kompetensi amil, LAZ di Jawa Timur lebih mengutamakan soft skill dan pengalaman bekerja dibandingkan dengan rumpun keilmuan atau gelar kesarjanaan tertentu. Kompetensi di bidang zakat dapat dilatih dan dipoles tanpa melihat pada aspek keilmuan khusus. 2) persyaratan amil zakat secara kelembagaan, sudah ditaati dengan baik. Hampir semua LAZ telah berbadan hukum dan memiliki legalitas yang kuat. Namun pada aspek usia amil 40 tahun, hal ini masih menuai protes karena pada usia tersebut bukan merupakan usia produktif. Maka hanya sebagian kecil LAZ yang melaksanakannya atau hanya pada dataran direktur atau pimpian saja. 3) dari aspek pelaporan, LAZ melakukan laporan baik enam bulanan yang berupa laporan keuangan kinerja dan laporan tahunan yang berupa keuangan, kinerja dan kelembagaan secara patuh. Bahkan LAZ juga melaporan keuangan dan kinerja kepada muzakki setiap bulan melalui website, majalah bulanan dan bentuk fisik lainnya.
\end{abstract}

Keyword : Efektifitas, UU Nomor 23 Tahun 2011, lembaga Amil Zakat

\section{Latar Belakang}

Sentralisasi kelembagaan zakat melalui Undang-Undang Nomor 23 tahun 2011 tentang Pengelolaan Zakat (UUPZ) merupakan ikhtiar pemerintah untuk melakukan pengendalian, pengawasan dan evaluasi lembaga zakat di Indonesia. Diantara upaya tersebut adalah menyatukan 
Badan Amil Zakat Nasional (BAZNAS) dan Lembaga Amil Zakat (LAZ) dalam satu payung kewenangan negara. Namun kenyataan berbicara lain, perundang-undangan ini dirasa kurang kooperatif dan membatasi prerogatif lembaga zakat. Kenyataan ini menimbulkan ambiguitas terhadap eksistensi lembaga zakat swasta.

Beberapa tahun terakhir, sembilan pengelola zakat swasta mengajukan keberatan terhadap UUPZ. Mereka meminta Mahkamah Konstitusi (MK) mengubah ketentuan pasal $18 \mathrm{UUPZ}$ di mana pasal tersebut berpotensi mematikan peran amil zakat swasta yang harus mengantongi izin tertulis dari pemerintah. ${ }^{1}$ Padahal tanpa ikatan serius (izin resmi) dari pemerintah, peran amil zakat berjalan efektif dan tidak ada pelanggaran hukum.

Melihat posisi lembaga zakat swasta yang dilematis-problematik, Forum Zakat (FOZ) menyimpulkan bahwa terdapat ambuguitas peran regulator, operator, koordinator dan pengawas dalam penataan lembaga zakat. Mereka menolak keberadaan perundang-undangan ini. ${ }^{2}$ Keberadaan undang-undang seharusnya dapat menguatkan hubungan kelembagaan antar lembaga zakat, bukan mendudukan BAZ sebagai badan resmi negara dan di waktu bersamaan melemahkan posisi LAZ yang selama ini justru menjadi pelopor dalam menajemen zakat.

Melalui putusan nomor 86/PPU-X/2012, MK memberikan solusi untuk menengahi problem kelembagaan zakat. MK memberikan kelonggaran pada pasal 38 dan 41, yakni dengan mencabut izin dan merubah dengan frasa "bersifat pemberitahuan amil". Sementara untuk pasal 18 yang awalnya seluruh LAZ harus berbadan hukum, kemudian tidak lagi mewajibkan, akan tetapi hanya menjadikannya fakultatif. ${ }^{3}$ Namun sayangnya, amar putusan tersebut menempatkan posisi LAZ sebagai pihak yang subbordinan.

\footnotetext{
${ }^{1}$ Ke sembilan lembaga zakat itu adalah Dompet Dhuafa, Yayasan Rumah Zakat Indonesia, Yayasan Portal Infaq, Yayasan Dana Sosial al-Falah Malang, Yayasan Yatim Mandiri, LPPZIZWAF Harum, Yayasan Harapan Dhuafa, Lembaga Manajemen Infaq dan YPI Bina Mandiri Mojokerto. Lihat dalam https://www.republika.co.id/berita/koran/newsupdate/13/11/01/mvinmf-mahkamah-konstitusi-revisi-uu-zakat diakses tanggal 3 Agustus 2019, pukul 08.05 WIB.

2 M. Yudistira Kusuma, "Respon Pengurus Forum Organisasi Zakat terhadap UndangUndang No. 23 Tahun 2011 tentang Pengelolaan Zakat", Skripsi UIN Jakarta (2013), hlm. 40.

${ }^{3}$ Niken Subekti Budi Utami, "Kriminalisasi Pengelolaan Zakat (Tinjauan Ketentuan Pasal 41 UU No. 23 Tahun 2011)", YUSTISA, Vol. 1 2013, hlm. 50.
} 
Hubungan antara LAZ dengan BAZ berubah menjadi up dan down, di mana keberadaan LAZ adalah untuk membantu BAZ.

Subbordinasi keduanya semakin kentara melihat pada aspek hubungan timbal-balik yang digambarkan oleh UUPZ, yakni LAZ harus melaporkan pelaksanaan pengumpulan, pendistribusian dan pendayagunaan zakat untuk diaudit secara berkala. ${ }^{4}$ Posisi demikian membuat LAZ berada di bawah aturan BAZ. Pada prosesnya, LAZ mesti mengikuti aturan yang tidak sesuai dengan cultur fungsi yang telah hidup sejak bertahun-tahun lamanya.

Fakta tersebut mengindikasikan bahwa stakholders atau lembagalembaga zakat yang telah lama menjalankan pemberdayaan dan pengelolaan zakat, merasa terbatasi dan gelisah dengan adanya aturan negara. Keberadaan UUPZ tidak mampu memberikan keamanan dan keadilan kepada masyarakat secara institutif. Perundang-undangan tersebut membutuhkan koreksi dan evaluasi untuk dilakukan perbaikan.

Riset mutakhir mencoba untuk mencari solusi dari problem kelembagaan zakat ini, diantaranya adalah melakukan penelitian di daerah yang memiliki LAZ berprestasi. Beberapa pengurus LAZ di Malang Jawa Timur berpendapat bahwa banyak pasal-pasal dalam UUPZ yang tidak sesuai dengan kondisi masyarakat, mengakibatkan tersendatnya pengelolaan zakat. Riset ini merekomendasikan adanya peninjauan ulang agar aturan zakat yang berskala nasional dapat berjalan paralel dengan cultur di masyarakat. ${ }^{5}$ Riset ini meminta pemerintah untuk menjadikan LAZ sebagai acuan dalam perumusan UUPZ.

Sama halnya dengan LAZ, ternyata BAZ juga demikian. Tahun 2010, riset dilakukan di Yogyakarta -saat itu UUPZ masih menggunakan aturan lama UU No. 38/1999- peneliti menyimpulkan untuk BAZDA Yogyakarta dari aspek manajemen zakat tidak sesuai dengan aturan yang ada (M.Sularno, 2010). ${ }^{6}$ BAZDA saja belum mengikuti aturan, apalagi untuk LAZ yang sejak kelahirannya tidak bergantung pada aturan negara. Hal ini

\footnotetext{
${ }^{4}$ Ibid., hlm. 62.

5 Trie Anis Rosyidah, "Implementasi Undang-Undang Nomor 23 Tahun 2011 terhadap Legalitas Pengelolaan Zakat oleh Lembaga Amil Zakat (Studi pada Beberapa LAZ di Kota Makasar)", Jurnal Ilmiah FEB, Vol 1 Nomor 1 tahun 2016.

${ }^{6}$ M. Sularno, "Pengelolaan Zakat oleh Badan Amil Zakat Daerah Kabupaten/Kota se Daerah Istimewa Yogyakarta (Studi terhadap Implementasi Undang-Undang No. 38 tahun 1999 tentang Pengelolaan Zakat)", Jurnal La_Riba, Vol. IV Nomor 1 2010, hlm. 36.
} 
mengindikasikan bahwa konsep sentralisasi lembaga zakat belum menemukan aturan yang koperatif.

Problem sentralisasi lembaga zakat menjadi perhatian akademisi. Dani Muhtada (2016) mengangkat hipotesa bahwa solusi yang tepat adalah memberikan kewenangan daerah untuk membuat Peraturan Daerah (Perda) tentang zakat. Muhtada meneliti tentang relevansi perda-perda zakat di seluruh Indonesia dengan UUPZ. Pada kesimpulannya, Muhtada menemukan bahwa Perda zakat merupakan pengulangan saja, tidak memberikan solusi praktis. ${ }^{7}$ Tentu, hal ini semakin memeruncing permasalahan lembaga zakat terutama di era otonomi daerah.

Dari problem sentralisasi lembaga zakat beserta riset yang dilakukan, penulis berkesimpulan bahwa problem tersebut belum terselesaikan. Diperlukan riset yang menyeluruh terhadap LAZ dan BAZ untuk menemukan konsep sentralisasi yang dicitakan oleh pemerintah. Hal ini penting dilakukan, mengingat banyaknya LAZ dan BAZ di Indonesia.

Hasil observasi pra-riset yang dilakukan penulis di beberapa LAZ dan BAZ serta studi dokumentasi, bermuara pada sebuah konsep sentralisasi yang bersifat otonom. Konsep tersebut penulis sebut yaitu otonomi zakat (zakat autonomy). Konsep tersebut sekilas menampilkan potret desantralistik lembaga zakat, namun tetap mangayomi semua lembaga zakat tanpa membatasi peran dan fungsi. Dengan demikian, penelitian ini akan menjawab problem sentralisasi zakat dan menyambut era otonomi zakah yang koperatif dan terukur.

Belakangan terakhir, banyak penelitian mengenai sentralisasi dan desantralisasi lembaga zakat, pendapatan zakat menjadi keuangan daerah dan Perda zakat. Pertama, penelitian dimuat di Jurnal Ziswaf yang diteliti oleh Dani Muhtada dengan judul "Payung Hukum Zakat di Era Otonomi Daerah: Menimbang Relevansi Perda Zakat Pasca UU No. 23 Tahun 2011" (2016). Muhtada menemukan beberapa temuan penelitian, yaitu; 1) 92\% Baznas memakai Perda sebagai aturan yang digunakan sebelum adanya UUPZ nomor 23/2011; 2) Perda zakat lebih relevan digunakan oleh LAZ daripada UUPZ. Hal demikian memberikan pekerjaan rumah bagi legislator

\footnotetext{
7 Dani Muhtada, "Payung Hukum Zakat di Era Otonomi Daerah: Menimbang Relevansi Perda Zakat Pasca UU Nomor 23 Tahun 2011", Jurnal ZIZWAF, Vol. 03 Nomor 1 2016, hlm. 67.
} 
untuk melakukan kajian ulang (re-interpreried) terhadap regulasi lembaga zakat di Indonesia.

Penelitian yang dilakukan oleh Yuni Sudarwati dan Nidya Waras Sayekti dengan judul "Konsep Sentralisasi Sistem Pengelolaan Zakat dalam Pemberdayaan Ekonomi Umat, (2018). Penelitian in menguji UUPZ melalui hipotesa bahwa LAZ kesulitan melakukan upaya sentralisiasi disebabkan oleh tidak adanya pemisahan fungsi regulasi, melalui pendekatan dokumentatif akhirnya peneliti berkesimpulan bahwa; 1) upaya sentralisasi lembaga zakat tidak dapat dilakukan mengingat LAZ tidak dilahirkan oleh kebijakan negara; 2) Sentralisasi lembaga zakat akan menjauhkan peran LAZ dari perannya sebagai lembaga zakat swasta yang efektif.

Penelitian dilakukan oleh Aden Rosadi dan Mohamad Anton Athoillah dengan judul "Distribusi Zakat di Indonesia: antara Sentralisasi dan desentralisasi", (2015). Metode penelitian yang digunakan adalah penelitian pustaka (library research) yang mengusung studi dokumentasi di beberapa LAZ Jawa Timur. Data-data yang dipaparkan diambil langsung dari sumber utama. Penelitian ini menawarkan konsep sentralisasi untuk pendistribusian zakat dengan mengacu pada teori integrasi.

Masih banyak hasil riset terdahulu yang pada kesimpulannya menginginkan adanya konsep desentralisasi lembaga zakat. Bahkan riset yang disampaikan di atas, merupakan perpaduan antara studi dokumentatif dan emperis, hasil penelitiannya lebih condong pada kritik UUPZ. Maka dari itu, penelitian penulis ini merupakan penelitian pengembangan yang diambil dari hasil penelitian terdahulu sebagai upaya menyelesaikan problem kelembagaan zakat melalui konsep zakat autonomy.

\section{Kajian Teori}

\section{Institusi Zakat dalam Islam}

Tidak dapat dibantah, pengelolaan zakat merupakan kewenangan ulil amri (pemerintah) baik secara langsung maupun pelantara. ${ }^{8}$ Maksud dikelola secara langsung adalah pemerintah sendiri yang mengumpulkan dan mendistribusikan zakat kepada mustahik. Sedangkan dikelola sebagai pelantara adalah lembaga lain seperti lembaga swasta yang mendapat izin dari pemerintah sesuai regulasi yang telah diatur.

\footnotetext{
8 Soni Santoso dkk., Zakat sebagai Ketahanan Nasional, (Yogyakarta: DEEPUBLISH, 2018), hlm.67.
} 
Statemen di atas merujuk pada nash al-Quran dengan petunjuh ghairu sharih fii ad-dalalah dalam surat at-Taubah ayat 60. Pada lafadz 'amilin dan faridhatan minallah menunjukkan bahwa pengelolaan zakat menjadi kewenangan ulil amri (pemerintah). ${ }^{9}$ Dengan kata lain, pengelolaan zakat harus diurus oleh lembaga pemerintah yang memiliki wewenang, bukan

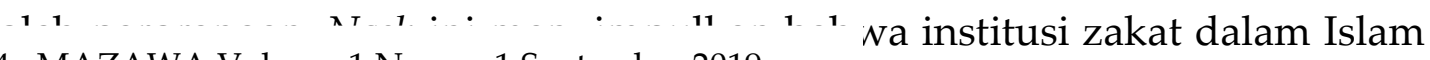
4 MAZAWA:Volume 1 Nomor 1 September 2019

Secara historisitas, sejak Islam mengkonsep zakat di bawah kewenangan negara, pengelolaan zakat telah dikooptasi oleh pemerintah. ${ }^{10}$ Hal ini bertujuan agar pengelolaan zakat dapat dikelola secara profesional dan tepat sasaran. Karena melalui kelembagaan, pengelolaan zakat dapat diawasi. Dalam hal ini, yang dimaksud kelembagaan bukan hanya pemerintah, lembaga zakat swasta non pemerintah juga masuk di dalamnya.

Dengan demikian, Islam mengatur agar zakat dijalankan melalui institusi kelembagaan. Baik kelembagaan yang langsung bentukan pemerintah maupun lembaga yang dibentuk oleh masyarakat secara mandiri. Oleh sebab itu, keberadaan LAZ dan BAZ sudah sesuai dengan dalalah nash.

\section{Konsep Desentralisasi dan Otonomi}

Pada tahun 1950'an, konsep desentralisasi tumbuh dan berkembang menjadi konsep yang mendapat perhatian khusus dan diakui sebagai kerangka kebiakan yang paling relevan untuk mengembangkan kekayaan lokal. ${ }^{11}$ Sampai pada akhir 1970'an, negara-negara berkembang terus membumikan konsep desentralisasi sebagai solusi memecahkan hubungan antara pusat dengan daerah yang saat itu menjadi phobia tak terselesaikan. ${ }^{12}$

Secara umum, konsep desentralisasi bukan hanya menyangkut hubungan negara dengan daerah, namun hubungan antara lembaga berstatus "negeri" dengan "swasta" juga masuk di dalamnya. Konsep ini menjadikan daerah (swasta, read) sebagai serpihan yang mandiri dalam mengelola sumber daya alamnya. Menurut Hans Kelsen desentralisasi

\footnotetext{
9 Oni Sahroni, Figh Zakat Kontemporer, (Depok: PT Raja Grafindo Persada, 2018), hlm. 265.

${ }^{10}$ Fuadi, Zakat dalam Sistem Hukum Pemerintahan Aceh, (Yogyakarta: DEEPUBLISH, 2016), hlm.105

${ }^{11}$ Ni'matul Huda, Problemetika Pembatalan Peraturan Daearah, (Yogyakarta: FH UII Press, 2014), hlm. 45.

${ }_{12}$ Haris Syamsuddin, Desentralisasi dan Otonomi Daerah: Naskah Akademik dan RUU Usulan LIPI, (Jakarta: LIPI Press, 2004), hlm. 55.
} 
menghasilkan tipe pemerintahan lokal yang a superior goverment, one encompassing a large jurdiction, assigns responsibility, authority, or function to lower govermnt unit. ${ }^{13}$

Maka dengan tipe ini, desentralisasi memiliki empat model yaitu dekosentrasi, delegasi, devolusi dan peralihan fungsi. Pertama dekonsentrasi, yaitu kemandirian daerah yang mencakup redistribusi tanggung jawab administrasi terhadap badan pemerintahan pusat. Kedua, delegasi yang dimaksud adalah pelimpahan kewenangan atau manajemen dari suatu daerah kepada daerah lain yang tidak berada di bawah kontrol langsung pemerintahan pusat. Ketiga adalah bentuk desentralisasi untuk memperkokoh satuan pemerintahan independen melalui devolusi peran dan kewenangan. ${ }^{14}$

Keempat model desentralisasi ini memiliki tugas pembantuaan (modevewind; co-administration; co-government) dari pemerintah pusat ke daerah (up to down). Menurut Koesoemahatmadja, medevewind dibuat dalam aturan bertujuan untuk mengukur kesuksesan pemerintah pusat dengan cara meminta bantuan kepada pemerintah yang ada di bawahnya. Konsep ini, menempatkan posisi antara atasan dan bawahan dalam term pemerintahan menjadi paralel.

Konsep paralelitas melalui otonomi ini pada prosesnya akan menumbuhkan pembaruan orientasi pembangunan dari top down ke bottom up yang mengisyaratkan bahwa mendorong pertumbuhan itu berangkat dari dalam (growth from inside). Dengan keleluasaan semacam ini, daerah otonom akan mengembangkan sumber dayanya secara mandiri dan maksimal di bawah koordinasi pemerintahan pusat.

\section{Teori efektifitas hukum}

Teori efektifitas hukum mengemuka di akhir abad 80'an. Saat itu, kritik terhadap hukum Indonesia getol disuarakan oleh masyarakat. ${ }^{15}$ Secara umum, teori ini adalah mengukur tingkat implementasi suatu aturan negara di masyarakat. Unsur memaksa dan mengatur, terkadang menjadikan aturan

\footnotetext{
${ }^{13}$ Hans Kelsen, Teori Umum tentang Hukum dan Negara, (Bandung: Nusamedia, 2006), hlm. 75.

${ }^{14}$ Hanif Nurcholis, Teori dan Praktek Pemerintahan dan Otonomi Daerah, (Jakarta: Grasindo, 2005), hlm. 27.

${ }^{15}$ Soejono Soekanto, Beberapa Aspek Sosial Yuridis Masyarakat, (Bandung: Alumni Press, 1985), hlm. 45 .
} 
tersebut di masyarakat menjadi facum. Akibatnya, aturan tidak dijalankan dan masyarakat menciptakan aturan sendiri.

Soejono Soekanto merupakan salah satu ahli sosiologi hukum yang menggencarkan teori efektifitas hukum dengan beberapa kriteria:

a. Menanamkan hukum dalam masyarakat sekaligus mengukur kemauan masyarakat untuk melaksanakannya;

b. Reaksi dan tanggapan masyarakat sebagai obyek hukum terhadap hukum yang telah dibuat oleh negara. Dalam term ini, teori efektifitas hukum menilik dari aspek prinsipil masyarakat yaitu alasan, motif, ketaatan mengikuti hukum;

c. Konteks hukum harus dinamis, dalam artian selalu sesuai dengan kondisi sosial masyarakat. ${ }^{16}$

Teori efektifitas hukum memiliki keniscayaan dalam sistem pembangunan di Indonesia, sehingga dibutuhkan keberadaannya. Ada beberapa argumentasi untuk dijabarkan terkait kenapa teori efektifitas hukum; 1) merupakan teori hukum yang hidup di Indonesia dan diciptakan oleh orang Indonesia dengan mempertimbangkan budaya masyarakat Indonesia itu sendiri; 2) teori efektifitas hukum menggunakan kerangka pandangan hidup sesuai kebutuhan Indonesia yang berlandaskan pada filsafat pancasila (norma, asas, institusi dan kaidah); 3) teori ini memberikan pijakan fungsi sebagai "sarana pembaharuan di masyarakat atau rekayasa sosial" (law as a tool of sosial engineering). ${ }^{17}$

Maka dengan demikian, fungsi hukum adalah mempertahankan ketertiban dan keteraturan -tujuan dari masyarakat yang sedang membangun- melalui kepastian hukum. Hukum harus membantu proses perubahan dalam masyarakat dan disesuaikan dengan hukum yang hidup di masyarakat. Kemudian, implemantasi fungsi hukum hanya dapat terwujud oleh suatu kekuasaan yang bekerja dalam rambu-rambu yang ditentukan oleh hukum.

\section{Metode Penelitian}

Penelitian ini termasuk dalam wilayah penelitian "Hukum dan Institusi" dengan pengkhususan pada wilayah pranata institusi, di mana

\footnotetext{
${ }^{16}$ Soejono Soekanto, Pokok-Pokok Sosiologi Hukum, (Jakarta: PT Raja Grafindo, 2007), hlm. 110. 17 Ibid., hlm. 113.
} 
hukum sebagai gejala sosial menjadi sasarannya. ${ }^{18}$ Wilayah ini berbanding lurus dengan jenis penelitian hukum fenomenologis di mana peneliti turun langsung ke lokasi penelitian. Jenis penelitian yang digunakan adalah penelitian kasus institusi (Case Study Research). Penelitian ini didekati dengan pendekatan komparatif (Comparative Approach). ${ }^{19}$ Perbandingan yang dimaksud adalah meneliti secara menyeluruh antara LAZ dan BAZ di Jawa Timur untuk mendapatkan data utuh.

Penetapan sumber data dalam penelitian ini dilakukan melalui teknik penetapan sampel bertujuan (purposive sample), ${ }^{20}$ kemudian hanya menggunakan sumber primer sebagaimana disebutkan pada lokasi penelitian. Pengumpulan data dalam penelitian ini diawali dengan pengumpulan dokumen, buku dan jurnal lain yang sesuai dan mendukung bagi penelitian, kemudian dilakukan dua metode pengumpulan data yaitu 1) wawancara (Interview). Teknik wawancara yang digunakan adalah wawancara mendalam (indepth Interview), di mana peneliti mengajukan pertanyaan-pertanyaan kepada informan sesuai kebutuhan penelitian. ${ }^{21}$ Untuk pemilihan Informan menggunakan teknik snow balling yaitu memilih informan kunci yang mempengaruhi bagi keluarga yang lain. 2) Dokumentasi. Teknik pengumplan data dengan dokumentasi ialah pengambilan data yang diperoleh melalui dokumen-dokumen.22 Bentuk dokumen di sini adalah segala dokumentasi yang tersedia di lembaga zakat.

Data yang terkumpul tidak langsung dijadikan data asli yang dibutuhkan dalam penelitian, namun dianalis secara interaktif, bila terjadi kekurangan pada kategori tertentu, dilakukan kembali pencarian data. ${ }^{23}$ Setelah Peneliti meyakini sudah lengkap, maka data-data tersebut dianalisa

${ }^{18}$ Cik Hasan Bisri, Pilar-Pilar Penelitian Hukum Islam dan Pranata Sosial (Jakarta : Grafindo Persada, 2004), hlm. 56.

${ }^{19}$ Peter Mahmud Marzuki, Penelitian Hukum, Cet. Ke-7 (Jakarta: Kencana, 2011), hlm.132.

${ }^{20}$ Sampel bertujuan dicirikan dengan : (1) rancangan sampel yang muncul tidak dapat ditentukan dan ditarik terlebih dahulu; (2) pemilihan sampel dilakukan secara berurutan; (3) penyeseuaian berkelanjutan dari sampel; dan (4) pemilihan berakhir jika sudah terjadi pengulangan. Lihat Lexy J. Meleong, Metodologi Penelitian Kualitatif Edisi Revisi, Cet. Ke-22 (Bandung : PT REMAJA ROSDAKARYA, 2006), hlm. 225.

${ }^{21}$ Burhan Bungin, Penelitian Kualitatif : Komunikasi, Ekonomi, Kebijakan Publik, dan Ilmu Sosial lainnya (Jakarta : Kencana Prenada Media Group), hlm. 108.

${ }^{22}$ Husaini Usman dan Purnomo Akbar, Metodelogi Penelitian Sosial, Cet. Ke-6 (Jakarta: Bumi Aksara, 2006), hlm. 73.

23Sugiyono, Metode Penelitian Kuantitatif Kualitatif dan R \& D (Bandung: Alfabeta, 2014), hlm. 246. 
melalui tiga tahap, yaitu : 1) mereduksi Data. Pada tahap ini, data dipilih yang penting-penting, disesuaikan dengan kategori dan dibuang yang tidak sesuai pertanyaan. 2) penyajian data. Setelah data direduksi, tampak hubungan-hubungan jawaban antara satu informan dengan informan yang lain dalam satu kategori yang sama. 3) penarikan kesimpulan. Setelah data disajikan dalam bentuk narasi yang berhubungan, selanjutnya data tersebut dapat menjawab dari permasalahan pada fokus penelitian. Jawaban tersebut kembali diuji ke lapangan untuk menjadi kesimpulan yang akurat.

Data yang terkumpul, pada tahap terakhir data dicek kembali sebelum sampai pada kesimpulan. Data diuji dengan triangulasi teknik, yaitu data yang terkumpul melalui wawancara kepada informan terpilih, dicek kembali melalui teknik yang berbeda, yaitu dengan pengamatan bebas. ${ }^{24}$

\section{Hasil Penelitian}

\section{Efektifitas UU No. 23 Tahun 2011}

Pengukuran efektifitas ini didasarkan pada tiga variabel utama yaitu persyaratan amil baik perorangan maupun kelembagaan, kompetensi amil dan sistem pelaporan lembaga zakat. Pemilihan ketiga variabel tersebut merupakan titik penting yang kerap mendapat sorotan oleh beberapa lembaga zakat termasuk juga yang menjadi point atau ayat pada pasal yang ditinjau kembali dan diputuskan oleh Mahkamah Konstitusi. Pengukuran efektifitas ini dilakukan pasca lahirnya putusan MK, sebab setelah itu nyaris tidak ada protes terang-terangan melalui jalur formal.

Pertama, persyaratan amil zakat. Sebagaimana diatur dalam Pasal 18 UU No. 23 Tahun 2011 (selanjutnya ditulis UUPZ) menyatakan bahwa pembentukan lembaga zakat swasta (selanjutna ditulis LAZ) harus mendapat izin dari pejabat yang ditunjuk oleh menteri. Selanjutnya pada pasal yang sama ayat 2, LAZ harus berbadan hukum untuk dikatakan sebagai LAZ yang legal. Pada bagian ini dari tiga penelitian yang dilakukan (LAZ DAU Sidoarjo, Yatim Mandiri dan Lazizmu) rerata semua LAZ mengikuti aturan dan berbadan hukum.

Sementara mengenai ketentuan amil zakat peroragan yang minimal harus berusia 40 tahun, sebagaimana diatur pada Pasal 11 UUPZ, ini sangat langka ditaati. Ketentuan usia 40 tahun kebanyakan hanya berlaku untuk direktur atau pimpinan LAZ. Sementara di jabatan di bawahnya berusia di bawah 40 tahun. Menurut sebagian sumber, pengurus atau amil lembaga zakat memang harus demikian, mengingat LAZ membutuhkan tenaga muda

${ }^{24}$ Sugiyono, Metode Penelitian Kuantitatif, hlm. 274. 
dalam mengelola, terutama pada bagian fundrising atau penghimpunan dana.

Alasan ini cukup logis, karena LAZ merupakan lembaga zakat yang mandiri dan otonom secara pemberdayaan dan kesejahteraan anggotanya. Maka untuk menjaga eksistensi lembaga, dibutuhkan kinerja yang tinggi dan loyal. Jika tidak, bukan tidak mungkin, kalau lembaga tersebut mesti gulung tikar, karena tidak ada asupan dana. Berbeda halnya dengan Badan Amil Zakat yang telah mendapat jaminan kesejahteraan dari pemerintah. Maka untuk tetap menjaga eksistensi LAZ, usia muda diperlukan untuk terus melakukan filantropi dan manajemen keuangan zakat yang produktif.

Kedua, kompetesi amil zakat. Mengenai kompetensi amil zakat yang diatur pada Pasal 11 UUPZ ayat " $\mathrm{h}$ ", dimana pengurus atau orang yang mengelola zakat harus memiliki kompetensi di bidang pengelolaan zakat terdapat banyak perbedaan. Perbedaan tersebut dapat ditelusuri dari pola rekruitmen yang dilakukan LAZ. Pola rekruitmen di LAZ DAU Sidoarjo menggunakan pola need is flor yaitu membuka seleksi amil pada posisi bidang tertentu yang dibutuhkan, semisal bagian keuangan maka hanya dibuka untuk bagian keuangan. Begitu juga untuk LAZ Yatim Mandiri, biasanya, dibuka secara serentak di beberapa bidang. Berbeda halnya dengan Lazizmu, biasanya, dibuka dan diutamakan untuk kader muhammadiyah.

Hanya saja, persyaratan untuk calon amil lebih bersifat umum secara keilmuan. Artinya, tidak melihat lulusan kesajarnaan tertetentu. Semua bidang lulusan atau sarjana apapun bisa mendaftar sebagai peserta seleksi. Baik sarjana teknik, pendidikan, hukum, politik, dan sebagainya. Akan tetapi, setelah mereka dinyatakan lolos seleksi, maka selama dua bulan akan diuji coba dulu melalui pelatihan manajemen zakat dan praktik kinerja langsung. Disitulah kompetensi amil sebagaimana disyaratkan oleh undangundang dapat dipertanggungjawabkan, karena amil sudah barang tentu memiliki kompetensi setelah ditimpa selama dua bulan.

Model asumsi ini ada benarnya, mengingat dalam aturan tersebut tidak dijelaskan secara rinci mengenai indikator penilaian kompetensi amil. Baik indokator dari segi keilmuan ataupun pendidikan. Sehingga untuk mengukur itu, wacana diadakan sertifikasi amil menjadi indikator penilaian. Maka dengan asumsi yang umum ini, LAZ tidak terikat untuk merekrut amil yang berkompetensi memahami zakat dan pola manajemennya. Karena LAZ memiliki kebijakan sendiri untuk mengukur kompetensi amil sebagaiman diamahkan oleh perundang-undangan.

Ketiga, pelaporan. Menurut ketentuan perundang-undangan, sistem pelaporan LAZ dan BAZ ada dua bentuk dan waktu. Yang pertama selama 6 bulan sekali brupa laporan keuangan dan kinerja dan kedua setahun sekali 
berupa laporan keuangan, kinerja dan kelembagaan. Bagi LAZ (karena in penelitian ke LAZ) pelaporan secara konsisten dilakukan setiap bulan sekali yang dipublis pada halaman web dan majalah bulanan. Laporan model ini diperuntukkan untuk muzakki secara spesifik sebagai bentuk akuntabilitas dan transparansi.

Setiap enam bulan sekali (1 semester) LAZ melakukan pelaporan keuangan dan kinerja. Bagi LAZ cabang seperti Yatim Mandiri, laporan enam bulanan langsung diserahkan ke pusat dan pusat meneruskan sebagai laporan lembaga diberikan kepada Kementerian Agama dan Baznas. Sementara bagi LAZ yang tidak memiliki cabang, langsung melaporkan pada Baznas Kabupaten dan Kementerian Agama setelah dilakukan audit internal atau audit akuntan publik.

\section{Penutup}

Setelah dilakukan penelitian dengan metode penelitian yang tapat dan akurat, ditemukan beberapa hasil penelitian sebagai simpulan akhir. Pertama, dari aspek kompetensi amil, LAZ di Jawa Timur lebih mengutamakan soft skill dan pengalaman bekerja dibandingkan dengan rumpun keilmuan atau gelar kesarjanaan tertentu. Kompetensi di bidang zakat dapat dilatih dan dipoles tanpa melihat pada aspek keilmuan khusus. Hal ini dapat dilihat dari aspek perekrutan calon amil yang tidak diharuskan atau disyaratkan dengan bidang ilmu khusus, namun siapa saja dengan keilmuan apapun dapat menjadi peserta, bahkan jenjang pendidikan tidak menjadi persyaratan, asal telah memiliki pengaralaman dan skill tertentu.

Kedua, persyaratan amil zakat secara kelembagaan, sudah ditaati dengan baik. Hampir semua LAZ telah berbadan hukum dan memiliki legalitas yang kuat. Namun pada aspek usia amil 40 tahun, hal ini masih menuai protes karena pada usia tersebut bukan merupakan usia produktif. Maka hanya sebagian kecil LAZ yang melaksanakannya atau hanya pada dataran direktur atau pimpian saja. Ketiga, dari aspek pelaporan, LAZ melakukan laporan baik enam bulanan yang berupa laporan keuangan kinerja dan laporan tahunan yang berupa keuangan, kinerja dan kelembagaan secara patuh. Bahkan LAZ juga melaporan keuangan dan kinerja kepada muzakki setiap bulan melalui website, majalah bulanan dan bentuk fisik lainnya.

Maka dari hasil penelitian tersebut, LAZ di Jawa Timur yang diwakili oleh tiga lokasi tersebut dapat dikatakan efektif dalam mentaati aturan UUPZ, baik pada aspek persyaratan amil, kompetensi amil dan mekanisme pelaporan manajemen zakat. Hanya saja, pada aspek kompetensi memang telah ambigu pada indikasi perudang-undangan tersebut dan memberikan ontomi kepada LAZ untuk menafsirkannyay sendiri. 
11 MAZAWA:Volume 1 Nomor 1 September 2019

Kinerja Lembaga Zakat di Indonesia", ZlZWWAF, Vol.6, No.1, 2019.

Bisri, Cik Hasan. Pilar-Pilar Penelitian Hukum Islam dan Pranata Sosial, (Jakarta : Grafindo Persada, 2004).

Brenen, Julia. Memadu Metode Penelitian : Kualitatif dan Kuantitatif (Yogyakarta : Pustaka Pelajar, 2005).

Fuadi. Zakat dalam Sistem Hukum Pemerintahan Aceh, (Yogyakarta: DEEPUBLISH, 2016).

Haris, Syamsuddin. Desentralisasi dan Otonomi Daerah : Naskah Akademik dan RUU Usulan LIPI, (Jakarta: LIPI Press, 2004).

Hastuti, Qurratul Aini Wara. “Urgensi Manajemen Zakat dan Wakaf bagi Peningkatan Kesejahteraan Masyarakat", ZIZWAF, Vol.1, No.2, 2014.

Jaelani, Aan. Manajemen Zakat di Indonesia dan Brunei Darussalam, (Cirebon: Nurjati Press, 2015)

Kelsen, Hans. Tori Umum tentang Hukum dan Negara, (Bandung: Nusamedia, 2006).

Khasanah, Umrotul. Manajemen Zakat Modern: Instrumen Pemberdayaan Ekonomi Umat,(Malang: UIN-Malang Press, 2010).

Marzuki, Peter Mahmud. Penelitian Hukum, Cet. Ke-7 (Jakarta: Kencana, 2011)

Meleong, Lexy J. Metodologi Penelitian Kualitatif, Cet. Ke-22 (Bandung : PT REMAJA ROSDAKARYA, 2006).

Muhtada, Dani. "Payung Hukum Zakat di Era Otonomi Daerah: Menimbang Relevansi Perda Zakat Pasca UU No. 23 Tahun 2011" ZIZWAF, Vol. 3, No.1, 2016.

Nurcholis, Hanif. Teori dan Praktek Pemerintahan dan Otonomi Daerah, (Jakarta: Grasindo, 2005).

Rosadi, Aden dkk., "Distribusi Zakat di Indonesia: antara Sentralisasi dan Desentralisasi", Ijtihad. Vol. 15 No. 2 tahun 2015.

Sahroni, Oni. Fikih Zakat Kontemporer, (Depok: PT Raja Grafindo Persada, 2018). 
Santoso, Soni dkk. Zakat sebr. DEEPUBLISH, 2018).

Silalahi, Gabriel Amin. Metode Penelitian dan Studi Kasus (Sidoarjo : Citra

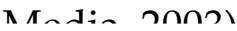

12 MAZAWA:Volume 1 Nomor 1 September 2019 di Asia Tenggara, (Malang: UIN-Malang Press, 2008).

Syafiq, Ahmad. "Urgensi Peningkatan Akuntabilitas Lembaga Pengelola Zakat", ZIZWAF, Vol.3, No. 1, 2016.

Wibisono, Yusuf. Mengelola Zakat Indonesia, Cet. Ke-2, (Jakarta: Prenadamedia, 2016). 